\title{
To Verdener mødtes
}

Taleved åbningen 8. oktober 1992 af Det Kongelige Biblioteks udstilling på Slotsholmen $i$ anledning af 500-året for opdagelsen af Amerika

af docent, dr.phil. Niels Fock

Det er uomtvisteligt, at to verdener mødtes for 500 år siden. Det er vel heller ikke så mærkeligt, at Spanien om 4 dage celebrerer den begivenhed, at Columbus og hans tre små karaveller stødte på Antillerne, det der successivt førte til at man tog lande i besiddelse, der langt overgik Spanien i størrelse. Det var jo også året, 1492, hvor Spanien som Nation etablerede sig, dels ved uddrivelsen af Maurerne, dels ved udgivelsen af den første grammatik over et moderne sprog, overhovedet - Nebrija's Gramatica Castellana, der etablerede det rigssprog, som skulle komme til at herske hjemme såvel som ude.

Med vanlig europæisk etnocentrisme så man på de amerikanske kolonier som "Den ny Verden", og megen harceleren er der blevet Columbus til del, fordi han stædigt fastholdt, at Amerika blot var bagsiden af den gamle Verden. Idag vil vi nok sige, at det var en ny gammel verden han fandt, og at den $\mathrm{Ny}$ Verden snarest var produktet af det historiske møde, at den ny verden kort sagt kom til at omfatte både Amerika og Europa - og ulykkeligvis også Afrika.

Dette møde mellem kontinenter, der igennem årtusinders isolation havde vokset sig forskellige, førte lige fra starten til en udveksling på globalt plan af uhørte dimensioner. Men det var - som vi jo ved - langtfra nogen lige udveksling. På et meget overordnet plan tror jeg man kan sige, at det var ulighed, der udveksledes med forskel. Ind - til Amerika - kom jo først og fremmest de hvide, men de kom som herrefolk, med en idiosynkratisk forestilling om deres meningers naturlige overlegenhed. Ud gik til gengæld hastigt voksende strømme af guld og især sølv, metaller af symbolsk og sakral værdi f.eks. i Inkariget, hvis sækularisering i Europa snart skulle vise sig at få fatale inflatoriske virkninger. Ind kom -allerede med Columbus' 2. rejse til Hispaniola 
i 1493 - forædlede produkter som heste, køer, svin, hvede, byg og sukkerrør. Man søgte at forbyde indianerne at ride, for at sikre sig deres underlegenhed, og som vi ved førte sukkerrørs plantagedriften til en række ulykker og degraderinger af først indianere siden afrikanere og til sidst af den naturlige vegetation i de tropiske regnskovsområder. Til gengæld for disse produkter fik Europa kartofler, majs og maniok, som idag brødføder millioner i vor verdensdel, foruden bønner, tomater, jordbær og ananas, tobak og meget andet godt.

Mest ulige - og katastrofal for indianerne - var imidlertid udvekslingen af sygdomme, som i kraft af Amerikas langvarige isolation og deraf følgende utilstrækkelig immunitet skulle vise sig at blive bestemmende for kontinentets skæbne.Spanierne og andre kolonister påførte sig ganske vist kønssygdomme som følge af det mere intime samkvem, men påførte til gengæld de indianske samfund epidemier af kopper, mæslinger og forkølelsessygdomme, der skønnes at have taget livet af fra 50 til $90 \%$ af den indianske befolkning. I de folkerigeste områder som Mexico og Peru var der - bogstavelig talt - tale om en decimering i løbet af det første århundrede, hvilket gjorde erobringen og overherredømmet muligt. Bartolomé de las Casas indignerede fremstillinger af folkedøden på Antillerne er en af de få samtidsberetninger om denne katastrofe.

I anledning af denne udstilling, der via bøger, tryk og manuskripter skal give et indtryk af mødet mellem to verdener, vil det jo være naturligt at stille spørgsmålet, hvilken udveksling der fandt sted m.h.t. ideer og tanker, tro og viden. $\mathrm{Og}$ - da vi befinder os i Det kongelige Bibliotek-hvordan det er gået med den skriftlige overlevering i så henseende. Hvad der tilflød indianerne var stort set begrænset til det kristne budskab, som i katolsk regi væsentligst udfoldede sig mundtligt og havde karakter af tvang ligesom alle andre spanske bekendtgørelser. Bortset fra Jesuiterne var det først med Protestantismen at en egentlig formidling på indfødte sprog fandt sted, fortrinsvis i form af bibeloversættelser som for eksempel til Algonkin. Egentlig missionsvirksomhed skabte kun sjældent grundlag for en forståelse. At denne forståelse desuden kun var envejs ser man ikke mindst af, hvordan spanierne forholdt sig til indianske traditioner.

En billedskrift fandtes allerede i det mexicanske område, og fra århundrederne op til erobringen producerede man lokalt, især i den sydlige del af området de berømte foldebøger, der bl.a. indeholdt kronologier, skabelses- 


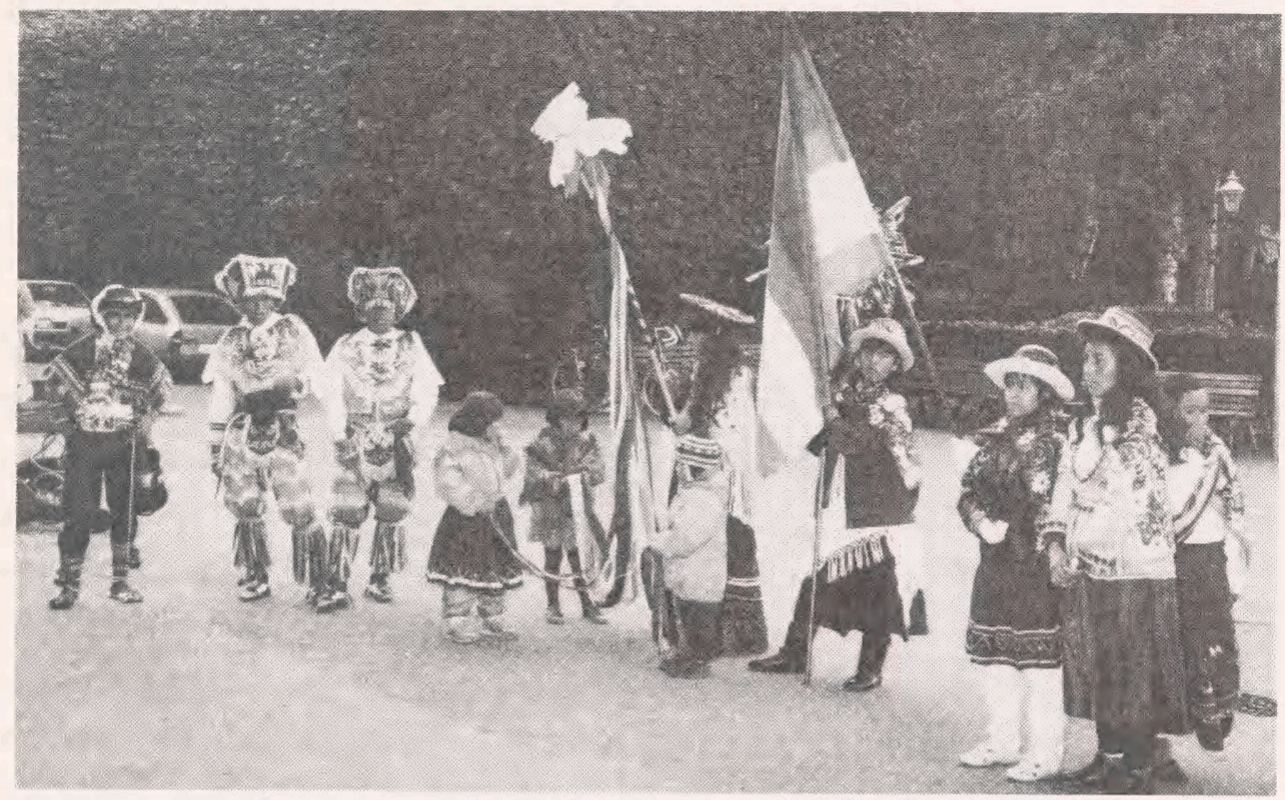

I forbindelse med udstillingen blev der 12. oktober 1993 foretaget en mindre rituel handling med dans og sang af peruanske indianere. Her ankommer peruanerne til biblioteket.

beretninger; og anden esoterisk viden. Ironisk nok bærer disse manuskripter idag navne som Dresden-kodexen, Pariser- og Madrid-codexen frem for mere naturlige angivelser som maya - eller mixteter-bøgerne. Deres skæbne er et helt igennem sørgeligt kapitel i europæisk åndsliv.

Meget tyder på, at der har eksisteret mange af den slags bøger, og de første munke, der virkede f.eks. i Maya-området, stødte på grupper af indfødte, der mødtes for at læse højt og recitere fra skrifterne. Dette medførte at de blev konfiskeret og tilintetgjort i stort tal. Den nidkære biskop Landa gennemførte således en større auto da féi Yucatan i 1562, hvor mængder af inskriptioner og bøger, optegnet og bevaret af maya-folk, blev flammernes bytte. Men nogle få forblev gemt hos maya'erne, der ligefrem mødtes i hemmelighed dybt inde i skoven,for ved højtlæsning at sikre den truede tradition. Det var på denne næsten Fahrenheit 451-agtige måde - at det nu så berømte Popul Vuh manuskript fra Chichicastenango i Guatemala igen blev nedskrevet på quiche-maya sprog men i spansk skrift. Ved et tilfælde faldt det i hænderne på den spanske præst Francisco Ximinez, der besad sprogkundskaber nok til ikke blot at kopiere men også oversætte teksten til spansk.

Dette skete i 1700-tallet. Da det lokale, dominikanske kloster blev lukket 
i 1800-tallet, forsvandt denne kopi imidlertid kort efter, men man fandt til alt held en kopi af kopien, der via Paris havnede i Chicagos Newberry Library, hvor man "fandt" det i 1928, så det kunne udgives i sin fulde udstrækning. Man kan forstå, at den formidling af maya-tanker, som deres bøger kunne have indebåret, kun mådeligt er blevet indfriet. I bedste fald er maya'ernes tanker om livet kun blevet en håndfuld forskere til del.

Mere umiddelbart tilgængelige var de spanske kronikørers skildringer fra de nys erobrede lande. Jeg vil nu vende mig mod Inkariget i Peru og omliggende lande, hvor nok den berømteste skildrer af Inkaernes liv og historie var Garcilaso de la Vega, halv-indiansk - af Inkaæt - halvt spansk, kort sagt mestiz, der i sin alderdom i 1609 i Spanien udgav sine "Kongelige kommentarer" et indforstået forsvar af Inkaernes civilisation, der skabte betydelig forståelse og interesse for inkaernes organisationstalent og moralske niveau.

Samtidig med Garcilaso var der imidlertid en quechua indianer, men fra barnsben opfostret i en spansk familie, ved navn Felipe Guaman Poma de Ayala, der skrev et kæmpeværk om livet i Peru fra de første tider til ca. år 1600. Guaman Pomas arbejde har en dobbelt interesse for os. Først fordi hans manuskript, som han i 1614 sendte til den spanske konge, ad ukendte kanaler endte i vort Kongelige Biblioteks håndskriftsamling engang før 1785. Dernæst fordi det først blev "fundet" her i 1908 og offentliggjort i facsimile-udgave i 1936, og i en almindelig læselig og kommenteret udgave så sent som 1980.

Det er - synes jeg - tankevækkende, at et værk der idag anses for det mest autentiske, autoritative og omfattende kildeskrift om Inkaernes historie, kultur og dagligliv, om mødet med spanierne og kolonitidens trængsler kunne være så længe undervejs til sit publikum. Det patetiskeer, at Guaman Poma har skrevet hele manuskriptet - på ikke mindre end ca 1.200 sider, hvoraf de 400 er meget værdifulde helsides tegninger - som understøttelse for et klagebrev til den spanske konge, Philip III, hvor han beder Kongen publicere værket, således at de spanske kolonisters overgreb og folkedrab kunne blive kendt for verden og forhindret for fremtiden. Titlen på hans manuskript "Den første nye krønnike og gode regering" har en utopisk klang. Guaman Poma håbede på et samfund, der kunne forene det bedste fra Inkacivilisationen med spaniernes religion og teknologi. Han havde, da han skrev, et budskab. Det var unægtelig længe undervejs, men det kom da - bl.a takket være Bibliotekets varetægt frem, og - vigtigst af alt - så har tiden vist, at Guaman Poma ikke skrev og 
Den peruanske indianer Salvador Palomino Flores, der er uddannet som antropolog, overbragte 12 . oktober med sine dansere og sangere en hilsen fra Perus indianere til det udstillede håndskrift Nueva Cronica y Buen Gobierno, Inkakrøniken, som har samme sakrale værdi for indianerrne, som de islandske håndskrifter har det for islændinge. Billedet her er fra bibliotekets Forhal.

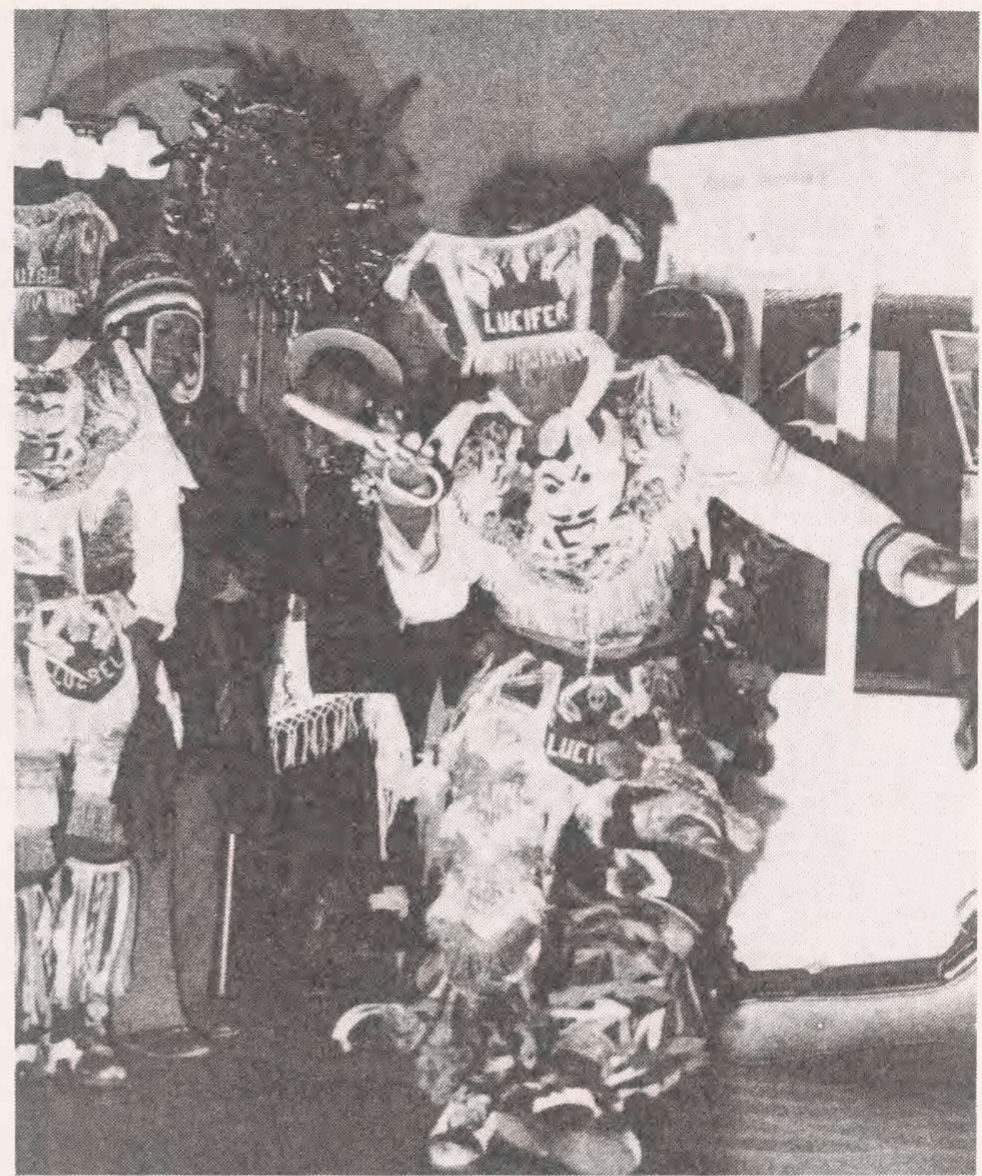

tegnede forgæves. En række af de indianerorganisationer, der i vore dage har fået mæle, takket være mere demokratiske tilstande i Peru, bruger ham som ideologisk grundlag for deres kamp og deres selvestimering. Manuskriptet er således ikke blot et musealt klenodie, dets budskab har overlevet-ligesom dets truede indianere trods alt har gjort det.

Verdener eksisterer kun gennem menneskers øjne, og de to verdener der mødtes var derfor den europæiske og den indianske. Disse verdener var dybt forskellige, men forskellene blev - i den gigantiske udveksling, som mødet satte igang, udmøntet i ulighed. Det er et fromt ønske, at denne 500-årige situation igen kan vendes, således at nysgerrighed og interesse, der jo netop udspringer af det fremmedartede og exotiske - og som jo også præger denne udstilling - kan føre til, at de to verdener også mødes i gensidig forståelse, sådan som vor berømte Guaman Poma slog til lyd for - for 378 år siden! 


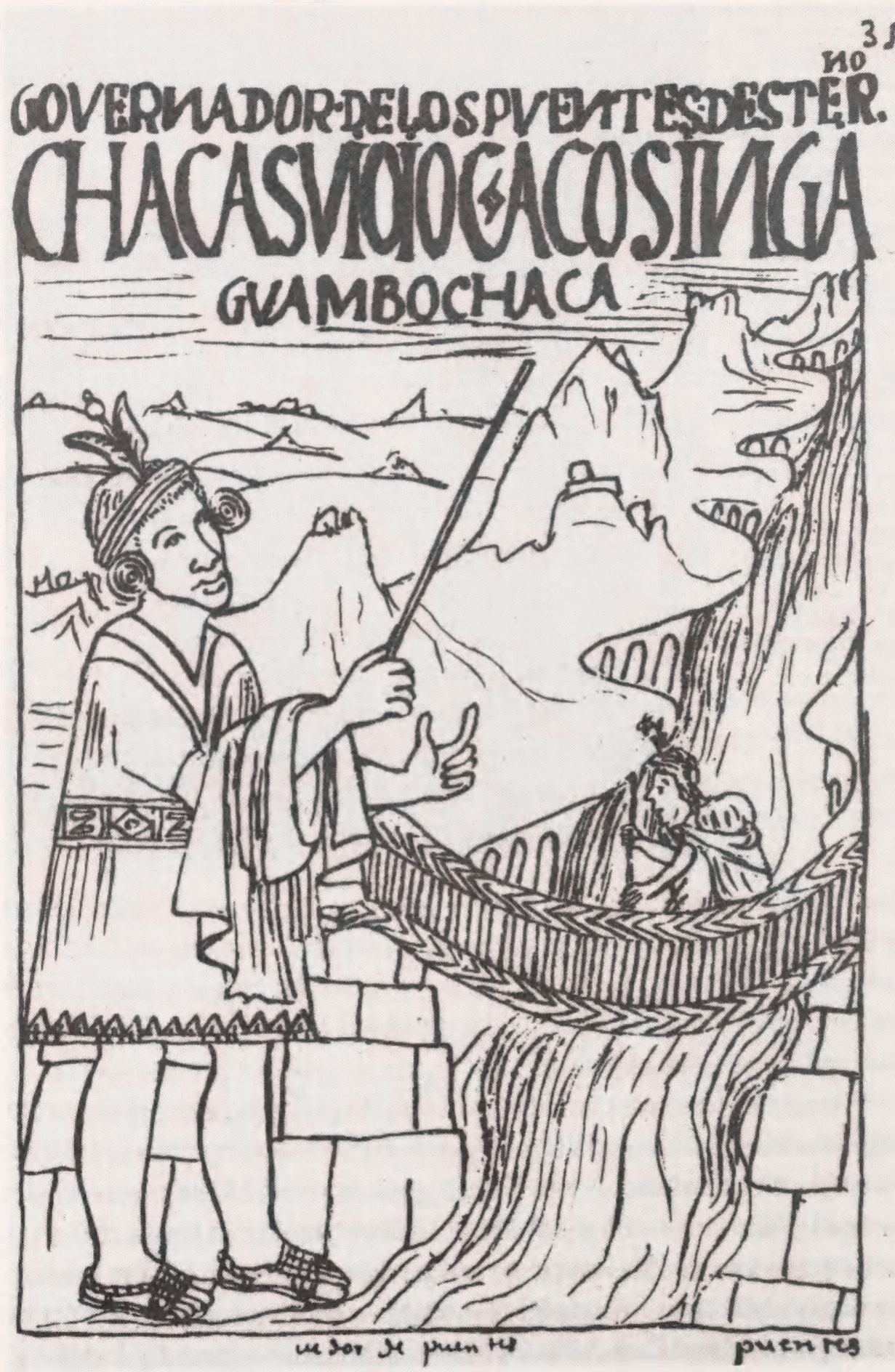

